\title{
Factors Leading to School Dropouts in India: An Analysis of National Family Health Survey-3 Data
}

\author{
Sateesh Gouda $\mathrm{M}^{1}$, Dr.T.V.Sekher ${ }^{2}$ \\ ${ }^{I}$ (Karnataka Health Promotion Trust (KHPT), Bangalore-560044) \\ 2 (International Institute for Population Science's (IIPS), Mumbai-400088)
}

\begin{abstract}
Education is the basic requirement for human development. With education, employment opportunities are broadened and income levels are increased. The development of an individual and the progress of a nation depend on education. The present article tried to understand the differentials and factors associated with school dropouts in India. Based on the data from National Family Health Survey-3, it was found that only 75 percent of the children in the age group 6 to 16 years were attending school. About 14 percent of the children never attended the school and 11 percent dropped out of school for various reasons. It was observed that the dropout was high among the children belonging to Muslim, Scheduled Caste and Scheduled Tribe families. Parental characteristics also play a significant role in determining school education. The dropouts among the children belonging to illiterate parents were four times higher than that of the literate parents. It was also observed that if parents were not working, the possibility of dropout among their children was relatively high. The study suggests that unless and until there is considerable improvement in the economic status of households and change in the social attitudes of parents, achieving the goal of universalisation of school education will remain a major challenge for India.
\end{abstract}

Keywords: Challenge for universalisation of education in India, Factors affecting school dropouts in India, Reasons for School dropouts in India, School dropouts in India.

\section{Introduction}

Education is the basic requirement for human development. With education, employment opportunities are broadened and income levels are increased. The development of an individual and the progress of a nation depend on education. It is also the principal instrument in awakening the child to cultural values and thus is the strongest force in the development and growth of a child in preparing him/her to be a responsible, intelligent, and capable citizen. Education is also equally important to improve the women's status and autonomy. It contributes to an increase in confidence and decision-making power within the household. In India, although the percentage of literacy is rising, what is alarming is that the number of illiterate children in the age group of 6 to 14 years is also increasing [1].

In 1990 at the World Conference on Education for All, governments agreed to a broad range of education goals including that of attainment of Universal Primary Education (UPE) by the year 2000. Sadly the millennium year had come and gone, but the UPE goal is still a distant dream, more so in developing countries like India. The millennium development goals as drawn up by the United Nations now directs nations to ensure that all boys and girls complete a full course in primary education by the year 2015 . While the government has been making concerted efforts aimed at expanding the reach of education, the phenomenon of school dropouts remains a blot on the progress of education in India. What is cause for particular concern is the enormity of the problem in most states of India and at all stages of school education where unacceptably high dropout rates have been reported [2]. The dropouts represent a significant human cost to children and the nation since they will most likely be permanently illiterate [3]. Illiteracy, poverty, inadequate earnings and poor living conditions of parents force them not only to withdraw their wards from schools but also put them in various types of jobs for contribution to the family income [4]. According to the United Nations Educational, Scientific and Cultural Organization [5] (UNESCO), India has the lowest public expenditure on higher education per student in the world. India spends just 3.5 percent of its gross domestic product on education, way below China's 8 percent, the public expenditure on education has actually declined from around 3.23 percent of GDP in 2000-01 to 2.88 percent in recent times. As a proportion of total government expenditure, it has declined from around 11.1 percent in 2000-01 to around 9.98 in recent years.

\section{Review of Literature}

Despite efforts to incorporate all sections of the population into the Indian education system, through mechanisms such as positive discrimination and non-formal education, large numbers of young people are still without schooling. Although enrolment in primary education has increased, it is estimated that at least 35 million and possibly as many as 60 million, children aged 6-14 years are not in school. Severe gender, regional, 
and caste disparities also exist. The main problems are the high drop-out rate, low levels of learning and achievement, inadequate school infrastructure, poorly functioning schools, high teacher absenteeism, the large number of teacher vacancies, poor quality of education and inadequate funds. The children 'at risk', such as orphans, child-laborers, street children and victims of riots and natural disasters, do not necessarily have access to schools [6].

Enrolment of all eligible children of school going age is an important step towards achieving 100 percent literacy. For various reasons children dropout at various levels of schooling the available studies on primary education in India have identified various reasons for why children drop out and why they remain unenrolled. The poor quality of schooling is responsible for low retention. Slum dwelling population is vulnerable due to associated influences such as low socio-economic status, lower parental literacy rates, high of juvenile delinquency, and low status of female children [7]. Levy [8] using data from 42 less developed countries tried to explore the relationship between social, political, economic and educational variables and the dropout rate from primary schools. It was found that school systems with high rates of repetition also have high dropout rates over the primary cycle. This suggests that automatic promotion may reduce educational wastage. While increased urbanization and development of communication systems increase school continuation. There is some evidence that the economic returns to education are important determinants of school continuation.

Borooah [9] examined a large Indian database and observed that while only 11 per cent of children lived in villages without a primary school, 30 per cent lived in villages without a middle school. A similar picture is reflected in urban areas. A neighborhood primary school is frequent while the same cannot be said about upper primary schools. Similar results have also been reported by Shariff [10] and Sengupta and Guha [11].The fact that dropout rate of Muslims is higher in India has also been borne out by the analysis carried out by Bhat and Zavier [12]. They argued that communities that took to education earlier had the advantage that was passed on to the next generation. Higher illiteracy or educational backwardness of Muslims is a legacy of the past. Consequently in urban India, following independence, upper caste Hindus were in a better position to take advantage of opportunities for secondary education than Muslims who lagged behind in primary education and literacy.

\section{Influence of family and household characteristics in school dropouts}

Choudhury [2] argued that as student moves from primary school to a higher stage of school, the chance of dropping out of school increases 2.7 times. The chance of Muslim student discontinuing is 1.9 times than that of Hindus. Further he mentioned that the total number of siblings has been found to be a highly significant predictor of school drop-out. An increase in family size by one increases the chance of dropping out 1.7 times. His analysis confirms that father's level of education is significantly related to dropout behaviour. For each higher class of father's education, the likelihood of a student dropping out reduces by 16 per cent. However "mother's primary education or middle level schooling did not have significant influence on dropouts". Sengupta and Guha [11] in their analysis of female dropouts in the state of West Bengal have observed that father's level of education is significantly related to dropout behaviour.

Husain [13] in his study found that the low level of literacy within the Muslim community is traditionally explained in terms of the conservative values characterizing Muslim society. Based on a field survey of slum dwellers in selected areas of Kolkata, he argues that economic factors and uncertainties in the labour market combine to create a different perception of the cost-benefits of education. Rao [4] also indicate that poverty is one of the main causes of drop out of girls. According to Upendranath [15] Indian education has been experiencing with high incidence of dropout at middle level (6th to 8th classes) and this is more for girls than boys. Data shows that in most countries, like India, more girls than boys drop out, resulting in a widening of the gender gap between primary and secondary and between secondary and tertiary enrolment ratios. Another study by Rao and Mohanty [14] concluded that the gender differentials in school enrolment and school attendance persisting in all the states. The school attendance varies directly with the economic condition

\section{Need for the Study}

Despite of governmental efforts, huge investment and many innovative programmes, the school dropout remains alarming high in many states. In this context, it is not only the provision of schooling facilities and quality of education, but also other household and social factors play a major role in influencing the discontinuation of education. It is very important to understand the family and parental characteristics to examine the reasons behind school dropouts. Though micro level studies and research based on departmental statistics have been undertaken by many scholars, National Family Health Survey -3 provides an opportunity to examine the school dropout, based on large nationally representative sample survey of households in Indian context. 


\section{Objectives}

- To understand the differentials in school dropouts at national and at state levels.

- To understand the main reasons for school dropout reported by household members.

- To examine the household and parental characteristics influencing the school dropouts in India.

\section{Data Source}

Data for this study has been obtained from the National Family Health Survey (NFHS-3), conducted in 2005-06. NFHS-3 provides information on fertility, mortality, family planning and important aspects of nutrition, health, and health care. Specific questions were asked to household respondent about schooling for children age 5-18 years. The questions include what was the highest standard the household member completed, did attended school anytime during the year 2005-06, what was the standard attending, school attendance in the previous year (2004-05) and standard, and most important reason for dropping out of the school if member is out of school. The available data on school dropout of children aged 6-16 years were analyzed to find out the extent of school dropout, stages of school dropout, household and parental characteristics of children who dropped out, and the reported reasons for discontinuing the school education. The school dropout in this article is defined as the children dropping out of the school from first standard to Tenth standard at any time and discontinuing their education. The analysis here is restricted to the age group 6-16 years since it broadly covers the school going age group up to Tenth standard.

\section{Analysis and Discussion}

Table 1: Percentage of children (aged 6-16 years) never attended school, attended some time, and currently in school: India, 2005-06.

\begin{tabular}{|c|c|c|c|c|}
\hline States & Never attended & $\begin{array}{c}\text { Attended some time and } \\
\text { discontinued }\end{array}$ & Currently in school & No. of Children \\
\hline Himachal Pradesh & 1.4 & 4.5 & 94.1 & 665 \\
\hline Uttarakhand & 4.9 & 8.5 & 86.5 & 1,091 \\
\hline Haryana & 9.7 & 10.8 & 79.5 & 2,609 \\
\hline Delhi & 7.3 & 8.8 & 83.9 & 1,335 \\
\hline Bihar & 33.7 & 6.6 & 59.7 & 11,571 \\
\hline Sikkim & 12.5 & 8.8 & 78.8 & 80 \\
\hline Arunachal Pradesh & 20.8 & 7.5 & 71.7 & 159 \\
\hline Nagaland & 17.9 & 7.2 & 74.9 & 195 \\
\hline Manipur & 10.0 & 7.0 & 83.0 & 229 \\
\hline West Bengal & 11.6 & 14.6 & 73.8 & 9,470 \\
\hline Jharkhand & 21.9 & 10.2 & 67.9 & 3,777 \\
\hline Orissa & 13.2 & 16.7 & 70.1 & 4,377 \\
\hline Chhattisgarh & 11.1 & 13.8 & 75.1 & 2,960 \\
\hline Madhya Pradesh & 14.8 & 10.7 & 74.5 & 8,208 \\
\hline Gujarat & 6.8 & 16.7 & 76.5 & 5,558 \\
\hline Maharashtra & 5.9 & 11.9 & 82.2 & 11,372 \\
\hline Andhra Pradesh & 8.8 & 15.3 & 75.9 & 7,981 \\
\hline Karnataka & 8.2 & 12.8 & 79.0 & 6,384 \\
\hline Goa & 2.4 & 6.5 & 91.1 & 123 \\
\hline Kerala & 0.5 & 3.9 & 95.6 & 2,489 \\
\hline Tamil Nadu & 1.3 & 9.6 & 89.1 & 5,190 \\
\hline
\end{tabular}

Table 1 presents the percentage of children (aged 6-16 years) never attended school, attended some time but presently not in school and those children currently in school for India and all the states. It shows that there was huge variation across the states which range from 0.5 percent (Kerala) to 34 percent (Bihar). It shows that India as whole, around 14 percent of the children had never attended school. Among the children never attended the school, Bihar was highest (34 percent) followed by Meghalaya (26 percent), Jharkhand ( 22 percent) and Arunachal Pradesh (21 percent). The states with low percent of children never attended school were Kerala ( 0.5 percent) followed by Tamil Nadu (1.3 percent), Himachal Pradesh ( 1.7 percent) and Goa ( 2.4 percent). The children attended the school some time but now not in school ranges from 4 percent (Kerala) to 17 percent (Gujarat and Orissa), India as a whole 11 percent of the children attended the school some time but presently they were not going to school called as school dropouts. Interestingly school dropouts rate was high in relatively 
better performing states i.e Gujarat (16.7 percent), Andhra Pradesh (15.3 percent) and West Bengal (14.6 percent), compared to Bihar (6.6 percent) and Jharkhand (10.2), however these states were performing better in children currently attending the school. Table 1 also shows the percent of children currently attending the school. India as a whole, 75 percent of the children were currently attending the school. Bihar was the state where lowest (60) percent of children attending the school followed by Meghalaya (67 percent), Jharkhand (68 percent) and Orissa (70 percent). Kerala (95.6 percent) has highest percentage of children in the school, followed by Himachal Pradesh (94.1 percent), Goa (91.1 percent) and Tamil Nadu (89.1 percent). It was important here to distinguish the children those who were not in school. Good proportion among them never went to school. However, another segment among them enrolled in school but dropped out later. This paper mainly focuses on the school dropout children and their characteristics and important reasons for school dropouts.

Table 2: Percentage of school dropouts (aged 6-16 years) by sex of the children: India, 2005-06

\begin{tabular}{|c|c|c|c|c|}
\hline State & Boys & Girls & Total & Number of Children \\
\hline Jammu and Kashmir & 8.4 & 10.7 & 9.4 & 1,083 \\
\hline Himachal Pradesh & 3.9 & 5.3 & 4.6 & 656 \\
\hline Punjab & 11.2 & 12.5 & 11.7 & 2,656 \\
\hline Uttaranchal & 7.1 & 11.0 & 9.0 & 1,037 \\
\hline Haryana & 11.0 & 13.0 & 11.9 & 2,355 \\
\hline Delhi & 10.4 & 8.5 & 9.5 & 1,238 \\
\hline Rajasthan & 10.4 & 18.6 & 13.9 & 6,857 \\
\hline Uttar Pradesh & 11.0 & 14.4 & 12.6 & 21,398 \\
\hline Bihar & 7.6 & 12.7 & 10.0 & 7,675 \\
\hline Sikkim & 11.1 & 8.8 & 10.0 & 70 \\
\hline Arunachal Pradesh & 9.0 & 10.2 & 9.5 & 126 \\
\hline Nagaland & 10.1 & 7.4 & 8.8 & 160 \\
\hline Manipur & 6.8 & 8.7 & 7.8 & 206 \\
\hline Mizoram & 11.1 & 12.5 & 11.8 & 102 \\
\hline Tripura & 10.8 & 11.4 & 11.4 & 387 \\
\hline Meghalaya & 11.2 & 9.4 & 10.3 & 292 \\
\hline Assam & 12.7 & 13.3 & 13.0 & 3,199 \\
\hline West Bengal & 16.0 & 17.0 & 16.5 & 8,373 \\
\hline Jharkhand & 11.7 & 14.8 & 13.1 & 2,950 \\
\hline Orissa & 17.5 & 21.3 & 19.3 & 3,801 \\
\hline Chhattisgarh & 12.8 & 18.2 & 15.5 & 2,630 \\
\hline Madhya Pradesh & 11.5 & 13.7 & 12.6 & 6,994 \\
\hline Gujarat & 14.6 & 21.8 & 17.9 & 5,178 \\
\hline Maharashtra & 10.2 & 15.2 & 12.6 & 10,701 \\
\hline Andhra Pradesh & 13.3 & 20.4 & 16.8 & 7,280 \\
\hline Karnataka & 11.6 & 16.3 & 13.9 & 5,862 \\
\hline Goa & 6.3 & 7.0 & 6.7 & 120 \\
\hline Kerala & 4.6 & 3.3 & 4.0 & 2,476 \\
\hline Tamil Nadu & 7.8 & 11.8 & 9.7 & 5,122 \\
\hline Total & 11.3 & 15.2 & 13.2 & $1,10,984$ \\
\hline
\end{tabular}

Table 2 examines the school dropouts (among the children aged 6-16 years who ever attended school) by sex of child for India and states. It can be seen from the table that at the national level, the dropout among girls was higher (15.2 percent) in comparison to boys (11.3 percent). In some states the gender difference in dropout was very high (in Rajasthan it was 8 percent point). The female dropout rate was very high in states like Gujarat (22 percent), Orissa (21 percent) and Andhra Pradesh (20 percent). The situation was contrary in states like Nagaland, Sikkim and Kerala where more male children were dropping out of school. In case of boys, the rural-urban difference was negligible. However, the dropout among girls was higher in rural areas (17 percent) compared to urban areas (12 percent) at national level.

Table 3: Percentage of school dropouts (aged 6-16 years) by stages of schooling: India, 2005-06

\begin{tabular}{|c|c|c|c|c|c|}
\hline State & Primary School & Middle School & High School & Total & $\begin{array}{c}\text { Number of } \\
\text { Children }\end{array}$ \\
\hline Jammu and Kashmir & 6.8 & 9.7 & 12.8 & 9.4 & 1,083 \\
\hline Himachal Pradesh & 2.0 & 6.9 & 4.5 & 4.6 & 656 \\
\hline Punjab & 6.8 & 16.6 & 15.0 & 11.7 & 2,656 \\
\hline Uttaranchal & 4.3 & 12.4 & 12.0 & 9.0 & 1,037 \\
\hline Haryana & 6.3 & 17.4 & 12.6 & 11.9 & 2,355 \\
\hline Delhi & 5.2 & 14.8 & 9.6 & 9.5 & 1,238 \\
\hline Rajasthan & 7.7 & 22.7 & 17.9 & 13.9 & 6,857 \\
\hline Uttar Pradesh & 6.0 & 20.2 & 20.2 & 12.6 & 21,398 \\
\hline Bihar & 8.3 & 13.8 & 10.4 & 10.0 & 7,675 \\
\hline Sikkim & 10.3 & 10.0 & 9.1 & 10.0 & 70 \\
\hline Arunachal Pradesh & 10.5 & 9.7 & 5.3 & 9.5 & 126 \\
\hline
\end{tabular}




\begin{tabular}{|c|c|c|c|c|c|}
\hline Nagaland & 9.0 & 8.9 & 8.0 & 8.8 & 160 \\
\hline Manipur & 4.7 & 10.3 & 11.9 & 7.8 & 206 \\
\hline Mizoram & 6.0 & 17.6 & 15.8 & 11.8 & 102 \\
\hline Tripura & 12.2 & 11.0 & 8.1 & 11.4 & 387 \\
\hline Meghalaya & 13.5 & 7.4 & 2.4 & 10.3 & 292 \\
\hline Assam & 13.7 & 14.0 & 9.2 & 13.0 & 3,199 \\
\hline West Bengal & 15.5 & 19.4 & 15.3 & 16.5 & 8,373 \\
\hline Jharkhand & 13.6 & 11.8 & 13.4 & 13.1 & 2,950 \\
\hline Orissa & 12.2 & 23.9 & 27.7 & 19.3 & 3,801 \\
\hline Chhattisgarh & 9.7 & 23.8 & 19.7 & 15.5 & 2,630 \\
\hline Madhya Pradesh & 8.7 & 17.3 & 14.9 & 12.6 & 6,994 \\
\hline Gujarat & 8.7 & 24.5 & 26.6 & 17.9 & 5,178 \\
\hline Maharashtra & 7.2 & 15.6 & 18.9 & 12.6 & 10,701 \\
\hline Andhra Pradesh & 10.0 & 24.1 & 18.3 & 16.8 & 7,280 \\
\hline Karnataka & 10.7 & 19.0 & 12.0 & 13.9 & 5,862 \\
\hline Goa & 5.1 & 7.7 & 9.3 & 6.7 & 120 \\
\hline Kerala & 1.8 & 3.1 & 6.3 & 4.0 & 2,476 \\
\hline Tamil Nadu & 4.3 & 10.2 & 13.8 & 9.7 & 5,122 \\
\hline Total & 8.7 & 18.1 & 16.3 & 13.2 & $1,10,984$ \\
\hline
\end{tabular}

Note: Primary School 1 to $5^{\text {th }}$ Standard, Middle school 6 to $8^{\text {th }}$ Standard, and High school- $9 \& 10^{\text {th }}$ standard

Table 3 shows the percentage of school dropouts (aged 6-16 years) by sex and stages of schooling, for India and its states. It was clearly indicates that as the stages of schooling increases the dropout rate was also increasing and more girls were dropping out of school than boys, which was true for most of the states. Broadly for the purpose of analysis, the primary school was taken as $1^{\text {st }}$ to $5^{\text {th }}$ standard, middle school as $6^{\text {th }}$ to $8^{\text {th }}$ standard and High school as $9^{\text {th }}$ and $10^{\text {th }}$ standards, though there were different types of classifications in various states.

Primary school level dropout was 9 percent for India as whole and it varies across the states from 1.8 (Kerala) to 15.5 percent (West Bengal). There were 12 states where primary school level dropout was higher than the country average, among them West Bengal (15.5 percent), Jharkhand, (13.6 percent), Assam (13.7 percent) and Meghalaya (13.5 percent) were reported highest dropouts in primary stage. At national level 18 percent of the children dropped out of school before completing middle school. Gujarat (24.5 percent) and Andhra Pradesh (24 percent) were top among the states where school dropout at middle school level was high followed by Chhattisgarh (23.8 percent) and Orissa (23.9 percent). At the high school level, 16 percent of the children dropped out at national level. In states like Kerala, Tamil Nadu, Goa, Mizoram, Manipur, Himachal Pradesh, Delhi, Haryana and Uttarakhand the dropout at the primary school level was relatively low compared to the dropout at the high school level. But in other states like Assam, West Bengal, Jharkhand, Orissa and Andhra Pradesh where the dropout levels at all the three stages were quite high. It was also true that the sex gap in school dropouts exists mostly in major states and gap increases as the stages schooling increases.

\section{Main Reasons for School Dropouts}

Table 4: Main reasons for school dropout by sex of the children: India, 2005-06

\begin{tabular}{|c|c|c|c|}
\hline Reasons & Boys & Girls & Total \\
\hline Not interested in studies & 37.2 & 22.3 & 29.8 \\
\hline Costs too much & 18.9 & 18.6 & 18.8 \\
\hline Required for household work & 7.8 & 16.1 & 11.9 \\
\hline Required for outside work for payment in cash/kind & 9.2 & 3.4 & 6.3 \\
\hline Repeated failures & 6.3 & 5.7 & 6 \\
\hline Required for work on farm/family business & 7.6 & 3.3 & 5.4 \\
\hline School too far away & 1.2 & 5.9 & 3.5 \\
\hline Further education not considered necessary & 2.8 & 4 & 3.4 \\
\hline Got married & 0.2 & 5.6 & 2.9 \\
\hline Did not get admission & 2.1 & 2.2 & 2.1 \\
\hline Not safe to send girls & 0.2 & 2.7 & 1.4 \\
\hline No proper school facilities for girls & 0.2 & 1.9 & 1.1 \\
\hline Transport not available & 0.3 & 1.6 & 1 \\
\hline Required for care of siblings & 0.2 & 0.7 & 0.5 \\
\hline No female teacher & 0.1 & 0.3 & 0.2 \\
\hline Other & 5.2 & 5 & 5.1 \\
\hline Don't know & 0.5 & 0.5 & 0.5 \\
\hline Number of Children & 6166 & 7400 & 13566 \\
\hline
\end{tabular}

Table 4 shows main reasons for school dropout by sex of the children for India. NFHS-3 provides the most important reason, as stated by the household members for the school dropout. At the national level, in 29 percent of the cases, the important reason cited was "child not interested in studies'. This reason was given for 36 percent of boys and 21 percent of girls who dropping out of school. For 19 percent of children, the reason mentioned was "Cost was too much". The two other important reasons mentioned by the households were 
'Required for household work' (12 percent) and 'Required for outside work for payment in cash or kind' (6 percent). Other reasons reported for dropping out of school includes 'repeated failures' 'required for work on form/family business', 'school too far away', and 'further education was not considered as necessary'. Interestingly, 3 percent of the cases at the national level reported marriage was the important reason for discontinuing education.

Further analysis indicates that, 6 percent of girls in rural areas and 2 percent in urban areas were dropped out of school, when they got married. Though NFHS provides only the most important reason for dropping out, it was possible that a combination of many reasons, along with the most important reason as cited by the household, must be responsible for discontinuing the children's education. We should also keep in mind that the important reason was stated by the household respondent, mainly by either of the parents or other family members, and was not given by the child who actually dropped out of school.

In general, one can assume that apart from school characteristics, the social and economic factors of the household contribute significantly for the discontinuation of children education. These reasons also vary among rural and urban areas, and among girls and boys. To make the analysis of reasons for school dropouts more meaningful, this article attempted to classify the important reasons into three broad categories-- Reasons related to children (Not interested in studies, Repeated failure, Got married), Reasons related to Household (cost too much, required for household work, Further education not considered necessary, Required for work on farm/family business, Required for care of sibling, Required for outside work for payment in cash or kind), School related reasons (school too far, Did not get admission, Transport not available, Not safe to send girls, No proper school facilities for girls, No female teacher). Though it may not be strictly possible to identify all the reasons as mentioned in the survey into these three broad categories, it will help us to understand how each of these factors responsible for the higher school dropout. This is important because, the improvement in school facility will help only to a limited extent. The improvement in economic condition of the household can have higher impact. Even the changes on social factors and attitudes will influence the education of the children considerably.

Table 5: School dropouts by reasons categorized as four groups and sex of children: India, 2005-06.

\begin{tabular}{lccc}
\hline Reasons & Boys & Girls & Total \\
\hline Reasons related to child & 43.7 & 33.6 & 38.6 \\
Reasons related to household & 46.5 & 46.2 & 46.4 \\
Reasons related to school & 4.1 & 14.7 & 9.4 \\
Other Reasons & 5.7 & 5.5 & 5.6 \\
\hline Number of Children & $\mathbf{6 , 1 6 6}$ & $\mathbf{7 , 3 9 9}$ & $\mathbf{1 3 , 5 6 6}$ \\
\hline
\end{tabular}

Note: The specific reasons included in each category are given in the text.

Table 5 shows School dropouts by reasons categorized as four groups and sex of children. It was interesting to know that at national level, 46 percent of school dropouts can be linked to household related factors (both among boys and girls). Child related reasons responsible for 44 percent dropouts among boys and 34 percent among girls (Table 5). School related factors contribute only 4 percent among boys and 15 percent among girls. Though many of these reasons are interrelated and one influences the other, the implications of each of these are quite different. Improvement in schooling facilities and infrastructure can only impact to a lesser extent in reducing the school dropouts. The household factors, both social and economic, need to be addressed more seriously to improve the present condition of higher dropouts.

\section{Determinants of school dropouts:}

It is important to examine the household characteristics of the children who were dropped out of school. It was believed that household factors were mainly responsible for children to discontinue their schooling, though it may vary between rural and urban areas, and among boys and girls.

Table 6: Percentage of school dropout by household characteristics: India, 2005-06

\begin{tabular}{llcc}
\hline Variable & Categories & Percent & No. of Children \\
\hline Religion & Hindu & 12.5 & 88,488 \\
& Muslim & 17.6 & 16,508 \\
& Others & 9.7 & 5,548 \\
\hline Caste & Scheduled Caste & 15.4 & 21,762 \\
& Scheduled Tribe & 16.4 & 8,969 \\
& Other Backward Classes & 12.7 & 45,175 \\
& None of the above & 11.1 & 32,023 \\
\hline Place of Residence & Urban & 11.9 & 32,833 \\
& Rural & 13.7 & 78,151 \\
\hline Household Size & 1 to 4 members & 13.8 & 23,168 \\
& 5 to 8 members & 12.8 & 67,618 \\
\end{tabular}




\begin{tabular}{llcc}
\hline Number Living Children & $1-2$ children & 5.5 & 20,938 \\
& 3 to 5 children & 11 & 55,604 \\
& 6 and above children & 16.2 & 12,796 \\
\hline Sex of Household Head & Male & 13.1 & 98,064 \\
& Female & 13.3 & 12,923 \\
\hline Land Holding & No Agriculture Land & 13.8 & 54,293 \\
& less than 1 hectare & 12.8 & 36,746 \\
& 1 to 5 hectares & 12.5 & 16,762 \\
\hline Standard of Living Index & 5 and above hectares & 9.3 & 3,186 \\
& Low & 17.2 & 27,564 \\
& Medium & 15.5 & 39,342 \\
\hline Total & High & 8.3 & 42,071 \\
\hline
\end{tabular}

Table 6 shows the percentage of school dropouts by household characteristics for India. The dropout among Muslim children was high compared to other religion groups. This was more significant in states like Gujarat and West Bengal. When we see the differentials at caste categories, considerable disparities still exists. The dropout was high among SC and ST children than the children belonging to OBC and general categories. The survey also indicates that the rural (13.7 percent) children were more likely to drop out of school than children living in urban (11.9 percent) areas. The researcher tried to examine whether household size has any significant influence on the school dropout? According to this survey, the reported difference was very minimal. However, the number of living children was a significant factor which determines the school dropout. The dropout increases considerably when the number of children increases. It was observed that the dropout was three times higher among the households having six and more children compared to households having one or two children. The level of dropouts comes down when size of the landholdings increases. This was more evident when we consider the standard of living Index. The dropout was almost double in low SLI (17.2 percent) families in comparison to high SLI (8.3 percent) families.

Table 7: Percentage of school dropouts by selected parental characteristics: India, 2005-06

\begin{tabular}{|c|c|c|c|}
\hline Factors & Categories & Percent & No. of Children \\
\hline \multirow[t]{4}{*}{ Education of Parents } & Both are illiterates & 17.1 & 22,857 \\
\hline & Both are literate & 4.6 & 27,000 \\
\hline & Mother is illiterate & 12.1 & 3,636 \\
\hline & Father is illiterate & 12.5 & 35,680 \\
\hline \multirow[t]{4}{*}{ Mother's Education } & No education & 14.4 & 49,963 \\
\hline & Primary & 9.6 & 14,265 \\
\hline & Secondary & 3.3 & 21,968 \\
\hline & Higher & 0.7 & 3,137 \\
\hline \multirow{4}{*}{ Father's Education } & No education & 16.5 & 25,872 \\
\hline & Primary & 13.9 & 16,343 \\
\hline & Secondary & 6.6 & 38,402 \\
\hline & Higher & 1.5 & 7,939 \\
\hline \multirow[t]{4}{*}{ Working status of Parents } & Father is working & 8.5 & 39,681 \\
\hline & Mother is working & 19.7 & 515 \\
\hline & Both are working & 13.2 & 41,802 \\
\hline & Both are not working & 17.5 & 763 \\
\hline \multirow[t]{3}{*}{ Father's Occupation } & Not working & 18.5 & 1,314 \\
\hline & Agriculture work & 12.7 & 30,666 \\
\hline & Non-agriculture work & 9.1 & 57,122 \\
\hline \multirow[t]{3}{*}{ Mother's Occupation } & Housewife & 8.1 & 43,834 \\
\hline & Agricultural work & 12.8 & 29,008 \\
\hline & Non-agriculture work & 12.5 & 16,455 \\
\hline \multirow[t]{3}{*}{ Mother's Exposure to mass media } & No Exposure & 13.8 & 25,880 \\
\hline & Partial Exposure & 9.2 & 51,987 \\
\hline & Full Exposure & 3.9 & 11,438 \\
\hline Total & & 13.2 & 89,333 \\
\hline
\end{tabular}

Note: This table was computed from eligible women file (linked based on household identification number) Media Exposure: No Exposure $=($ not listening radio, not reading newspaper, not watching T.V), Partial exposure $=($ either listening radio, reading newspaper, watching T.V), Full exposure $=($ listening radio and reading newspaper and watching TV)

Table 7 shows Percentage of school dropouts by selected parental characteristics for India. Apart from household factors, School dropouts can be contributed by parental characteristics. An attempt was made to understand how far parental characteristics may influence the discontinuation of schooling of their children. Earlier studies (Husain, 2005) [13] also observed that parental education was crucial in improving the school education of children. According to this analysis, the dropout was four times higher among the children of 
illiterate parents than that of literate parents. The work status of parents particularly that of father, was also very important. The dropout was higher among the children where both parents were not working (17.5 percent). If father was not engaged in any economically productive activity, the dropout among children was still higher (18.5 percent). The exposure to mass media increases among the mothers, the likelihood of dropouts of their children decline considerably.

\section{Multivariate analysis}

Table 8: Odds ratio of school dropouts by selected predictors: India, 2005-06

\begin{tabular}{|c|c|}
\hline Predictors & $\operatorname{Exp}(\mathbf{B})$ \\
\hline 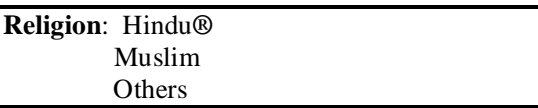 & $\begin{array}{l}1.60^{*} \\
0.95\end{array}$ \\
\hline $\begin{array}{l}\text { Caste: Scheduled Caste® } \\
\text { Scheduled Tribe } \\
\text { OBC } \\
\text { None of the above }\end{array}$ & $\begin{array}{l}0.89^{*} \\
0.87^{*} \\
0.82^{*}\end{array}$ \\
\hline $\begin{array}{cc}\text { Place of residence: } & \begin{array}{c}\operatorname{Rural}^{\circledR} \\
\text { Urban }\end{array} \\
\end{array}$ & $1.33^{*}$ \\
\hline $\begin{aligned} & \text { Household Size: } 1 \text { to } 4 \text { members } ® \\
& 5 \text { to } 8 \text { members } \\
& 9 \text { and above } \\
&\end{aligned}$ & $\begin{array}{l}0.56^{*} \\
0.50^{*}\end{array}$ \\
\hline $\begin{array}{ll}\text { No. of Living Children: } & 1-2 \text { children }{ }^{\circledR} \\
& 3 \text { to } 5 \text { children } \\
& 6 \text { and above } \\
\end{array}$ & $\begin{array}{l}2.28^{*} \\
3.28^{*} \\
\end{array}$ \\
\hline $\begin{array}{rc}\text { Sex of Household Head : } & \text { Male® } \\
& \text { Female }\end{array}$ & 0.94 \\
\hline $\begin{array}{l}\text { Agricultural Land: } \text { No Land® } \\
\text { less than } 1 \text { hectare } \\
1 \text { to } 5 \text { hectares } \\
5+\text { hectares }\end{array}$ & $\begin{array}{l}0.83^{*} \\
1.00 \\
0.85\end{array}$ \\
\hline $\begin{array}{r}\text { Standard of Living Index: Low }{ }^{\circledR} \\
\text { Medium } \\
\text { High } \\
\end{array}$ & $\begin{array}{l}0.97 \\
0.67^{*}\end{array}$ \\
\hline $\begin{array}{c}\text { Couples Education : } \text { Both are illiterate }{ }^{\circledR} \\
\text { Mother is illiterate } \\
\text { Father is illiterate } \\
\text { Both are literate }\end{array}$ & $\begin{array}{l}0.73^{*} \\
0.72^{*} \\
0.37^{*}\end{array}$ \\
\hline $\begin{array}{cc}\text { Parents Occupation: } & \text { Both not working }{ }^{\circledR} \\
& \text { Mother is working } \\
\text { Father is working } \\
\text { Both are working }\end{array}$ & $\begin{array}{l}1.97^{*} \\
2.07^{*} \\
1.35^{*}\end{array}$ \\
\hline $\begin{aligned} \text { Mother's Media Exposure : } & \text { No exposure } \AA \\
& \text { Partial Exposure } \\
& \text { Full exposure }\end{aligned}$ & $\begin{array}{l}1.01 \\
0.67^{*}\end{array}$ \\
\hline Constant & 0.14 \\
\hline -2 Log likelihood & 42949.9 \\
\hline R Square & 0.098 \\
\hline
\end{tabular}

Notes:

Dependent variable School Dropout ( $0=$ No, $1=$ Yes $)$

* indicates the odds ratio is significant at 1 percent level

** indicates the odds ratio is significant at 5 percent level,

(B) indicates reference category,

Table 8 presents Odds ratio of school dropouts by selected predictors in India. In order to isolate the effects of independent variables on dependent variable, multivariate analysis resorting to logistic regression was carried out. To get the effect of each variable on school dropout in the logistic regression, three models were experimented. The dependent variable was school dropout $(1=$ Yes, $0=\mathrm{No})$. In the first model, only the household related characteristics of children were considered, in the second model only parental characteristics of children were taken and in the third model household as well as parental characteristics of children were incorporated. Model 3 logistic regressions was adopted because the value of $-2 \log$ likelihood was lowest for the model 3 and also the value $\mathrm{R}^{2}$ increased compared to other models.

The results of logistic regression show the effect of household and parental characteristics on school dropouts. It was seen from the table that the household sizes, number of living children, parents' education were the important and significant predictors of school dropout. In India, the children belonging to the households having 9 and more members were 0.5 times less likely to continue schooling compared to small size families. It 
shows that if both parents were literate, the dropout chances were likely to reduce by 0.6 times at 1 percent level of significance compared to children of illiterate parents. Children belonging to Muslim households were 1.6 times more likely to drop out of school; children of high SLI families were 0.3 times less likely to discontinue education compared to low SLI children. The likelihood of dropping out was 3 times higher in India, if the number of living children were six and above.

\section{Conclusions And Policy Implications}

The present article tried to understand the differentials and factors associated with school dropouts in India. Based on the data from NFHS-3, it was found that only 75 percent of the children in the age group 6 to 16 years were attending school. About 14 percent of the children never attended the school and 11 percent dropped out of school for various reasons. As expected, the gender differentials were still persisting in school education. The dropout was higher among girls (15 percent) than boys (11 percent). With regard to rural- urban differences, more girls dropped out in rural areas (17 percent) than in urban areas. The gender differential in school dropout was negligible in urban areas. According to this analysis, the dropout was higher at the middle school level (18 percent) and also at high school level (16 percent), where as the dropout at primary school level was around 9 percent in India. Those states with better educational attainment, the dropout rate was low at primary school level and more at high school level.

The study also examined the household and parental characteristics which were possibly influence the school dropouts. In general, it was observed that the dropout was high among the children belonging to Muslim, Scheduled Caste and Scheduled Tribe families. With the increase in the land holdings of the households, there was a decline in the school dropouts. The standard of living index also shows that children belonging to low SLI families were more likely to dropout. Parental characteristics also play a significant role in determining school education. The dropouts among the children belonging to illiterate parents were four times higher than that of the literate parents. It was also observed that if parents were not working, the possibility of dropout among their children was relatively high. The multivariate analysis indicated that the household size, number of living children, and parental education were the most important predictors of school dropouts in India.

The major reasons cited by the households for the dropout were 'children were not interested in studies', 'cost was too much', 'children were required for household work' and also for work outside to contribute to family income. Nearly 6 percent of the girls dropped out of school when they got married. An attempt was made in this paper to categorize the most important reasons given by the households for their children's dropout. According to this grouping, household factors were responsible for nearly 46 percent of the dropouts. School related factors, like poor infrastructure, lack of teachers, etc, were contributing for 15 percent dropout among girls and 4 percent among boys. It is important to emphasis here that improving the school infrastructure, quality of education and huge investment in school education can only reduce the extent of dropout to a limited extent. Unless and until there is considerable improvement in the economic status of households and change in the social attitudes of parents, achieving the goal of universalisation of school education will remain a major challenge for India.

\section{References}

[1]. Sharma, Ruchita, Shubhangna Sharma and Shipra Nagar, (2007), "Extent of Female School Drop outs in Kangra District of Himachal Pradesh", Journal of Social Science, 15(3): 201-204.

[2]. Choudhury, Amit (2006), "Revisiting Dropouts: Old Issues, Fresh Perspectives", Economic and Political Weekly, December 16.

[3]. Desai, Uday (1991), "Determinants of Educational Performance in India: Role of Home and Family", International Review of Education, Vol. 37, No. 2 pp. 245- 265

[4]. Rao, Mohan, M.J. (2000). "Migration of labour and school dropouts", Social Welfare, 47(6): 26-31

[5]. United Nations Educational, Scientific and Cultural Organization (UNESCO) 1989 and 2007, Statistical Yearbook Paris: UNESCO

[6]. Lall, Marie, (2005), "The Challenges for India's Education System”, Chatham House, New Delhi,

[7]. Pratinidhi, A.K., Warerkar S.V and S.G. Garad, (1992), “A study of school dropouts in an urban slum community”, Demography India, vol. 21 No.2 pp. 301-305

[8]. Levy, Mildred B, (1971), "Determinants of Primary School Dropouts in Developing Countries" ,Comparative Education Review, Vol. 15, No. 1 (Feb.,), pp. 44-58

[9]. Borooah, Vani K (2003): 'Births, Infants and Education: An Econometric Portrait of Women and Children in India', Development and Change, 34, pp 67-102.

[10]. Shariff, Abusaleh (1995): 'Socio-Economic and Demographic Differentials between Hindus and Muslims in India', Economic and Political Weekly, 18, pp 2947-53.

[11]. Sengupta, P and J Guha (2002): 'Enrolment, Dropout and Grade Completion of Girl Children in West Bengal', Economic and Political Weekly, 37(17), pp 1621-37.

[12]. Bhat, P N Mari and A J Francis Zavier (2005): 'Role of Religion in Fertility Decline: The Case of Indian Muslims', Economic and Political Weekly, XL, 5, pp 385-402.

[13]. Husain, Zakir (2005), "Analysing Demand for Primary Education Muslim Slum Dwellers of Kolkata", Economic and Political Weekly, January 8, 2005

[14]. Rao, Rama G and. Mohanty S.K, (2004), "School Enrolment and Dropout: Policies and Achievements", Paper presented in seminar on follow-up of the National Population Policy- 2000: Focus on EAG states, 25-27 Oct. 2004.

[15]. Upendranath, C. (1995). "Education of girls in India: The daunting task ahead." Journal of EducationalPlanning and Administration, 9: 81-92. 